\title{
HORMONAL PROFILE ASSOCIATED WITH ESTABLISHMENT OF PREGNANCY IN FRIESIAN COWS IN RELATION TO SUMMER CONDITION IN EGYPT
}

\author{
S. A. Swiefy ${ }^{1}$, F. E. El-Keraby ${ }^{1}$, S. A. Essawy ${ }^{2}$ and A. H. Barkawi ${ }^{3}$ \\ 1- Department of Animal Biotechnology, Animal Production Research Institute, \\ 2- Department of Animal Biology, Animal Reproduction Research Institute, \\ 3- Department of Animal Production, Faculty of Agriculture, University of Cairo, \\ Giza, Egypt
}

\section{SUMMARY}

The present study was carried out on 16 multiparous Friesian cows inseminated during summer season (June and August) to compare between the hormonal profile of pregnant and non-pregnant cows within the period of pregnancy establishment (maternal recognition). Estrus was checked three times daily, and a cow that was recognized to be on heat was inseminated with frozen semen 8-16 hrs from the beginning of heat. Blood samples were collected daily from the day of insemination up to day 21 post-insemination to determine the concentrations of progesterone, while $P G F_{2}$ and $P G E_{2}$ concentrations were determined throughout the period from day 12 to day 20 (period of maternal recognition in pregnant cows). Pregnancy diagnosis took place 45 days post-insemination using rectal palpation. According to the results of pregnancy diagnosis, animals were allocated into two groups $(n=8$ each), pregnant $\left(G_{1}\right)$ and non-pregnant $\left(G_{2}\right)$.

Results indicated that pregnant cows had higher levels of progesterone and $P G E_{2}$ than cows of $G_{2}$, while $P G F_{2 \times}$ levels was lower than in non-pregnant ones. During the period of maternal recognition (day 16 and 17 ) $P G F_{2} / P G E_{2}$ ratio was $1: 4$ and 1:7 in $G 1$ and $G 2$, respectively.

Keywords: Friesian, maternal recognition, progesterone, $\mathrm{PGF}_{2 \mathbb{\mathbb { E }}}, \mathrm{PGE}_{2}$

\section{INTRODUCTION}

Season of year has a significant influence on embryonic mortality (Hansen et al., 2001) and reproductive failure (Hansen and Arechiga,1999). Friesian cattle were introduced to Egypt to bridge the gap of milk demand and supply. Previous studies indicated that their reproductive performance is lower during summer of Egypt compared to winter (El-Keraby and Aboul-Ela, 1982) which could be most probably due to the effect of heat stress (Hansen et al., 2001 and Al-Katanani et al., 2002)

Embryonic mortality before day 18 of pregnancy is one of the major reasons causing reproductive dysfunction in cattle (Dunne et al., 2000). One of the reasons of this phenomenon is the failure in luteotrophic mechanism(s), which is necessary to keep high concentration of progesterone $\left(\mathrm{P}_{4}\right)$ during pregnancy (Mann and Lamming, 2001; Spencer and Bazer, 2002 and Inskeep, 2004). Luteotrophic mechanism is a complicated process, in which pituitary gland, embryo, uterine endometruim and ovaries are share in.

Issued by The Egyptian Society of Animal Production 
Many studies were conducted to describe the hormonal balance during pregnancy with particular emphasis on the time of maternal recognition (days 12-18 post insemination) in to understand the luteotrophic mechanism in cattle (Schams and Berisha, 2004). Oyedipe et al. (1986) and Peters (1996) found that $\mathrm{P}_{4}$ was higher in pregnant than in non-pregnant cows due to maintenance of corpus luteum (CL). Parent et al. (2002) and Inskeep (2004) reported that $\mathrm{PGE}_{2}$ concentration is greater in pregnant than in non-pregnant animals during day 17 after insemination. On the contrary, $\mathrm{PGF}_{2 \mathrm{k}}$ was less in pregnant than in non-pregnant one (Asselin and Fortier, 2000 and Parent et al., 2002).

Up to the knowledge of the authors, no data are available to describe the hormonal balance during the maternal recognition period of Friesian cattle under Egyptian summer environment, which was the aim of the present study.

\section{MATERIALS AND METHODS}

\section{Animals and Management}

The present study was carried out at EL-Karaada Animal Production Research Station, Agriculture Research Center, Ministry of Agriculture and Land Reclamation, Egypt, in the Nile delta. Purebred multiparous Friesian cows (between the $2^{\text {nd }}$ and $4^{\text {th }}$ parities and 4-6 years of age) inseminated during June and August were used in this study. Estrus was observed three times daily and cows in heat were inseminated with frozen semen 8-16 hrs after the beginning of heat.

Cows were housed in a semi-shaded yard and fed on dry feed composed of concentrate mixture plus rice straw to cover their requirement calculated according to NRC (1988) allowances. Clean water for drinking was available all the time. Dams were allowed to nurse their calves four days pot-partum before being machine milked twice daily

Pregnancy was checked 45 days post-insemination applying rectal palpation. After pregnancy diagnosis eight pregnant cows (G1) and eight non-pregnant ones (G2) were allocated as two experimental groups.

\section{Blood Sampling and Hormonal Assay}

Daily blood samples were collected from day 1 to day 21 post-insemination before being collected regularly at 3 - 4 day interval till day 45 post-insemination. In the case of estrus return during the 45 days post insemination, sampling collection was discontinued and the cow was considered non-pregnant. Blood samples were collected before drinking in the morning $(07: 30 \mathrm{hr})$ from the jugular vein into heparinized tubes. Progesterone was measured throughout the period from day 1 to day 20 days post-insemination, and $\mathrm{PGF}_{2 \mathrm{~d}}$ and $\mathrm{PGE}_{2}$ concentrations were determined throughout the period from day 12 to day 20 days post-insemination (maternal recognition period; Peters, 1996). After collection, samples were centrifuged at $3000 \mathrm{rpm}$ for 15 minutes for plasma separation before being stored at $20 \mathrm{C}$ till the time of assay.

Plasma progesterone $\left(\mathrm{P}_{4}\right)$ concentration was carried out using ready coated radioimmunoassay kits ( Immunotech, France). The sensitivity of the assay was reported to be $0.03 \mathrm{ng} / \mathrm{ml}$. Intra- and inter-assay coefficients of variation were 4.3 and $8.2 \%$, respectively. The standard curve ranged between 0.1 and $50 \mathrm{ng} / \mathrm{ml}$. while the cross reaction of the antibody was $8.8 \%$. 
Prostaglandin $\mathrm{F}_{2 \star} \quad\left(\mathrm{PGF}_{2 \star}\right)$ and prostaglandin $\mathrm{E}_{2}\left(\mathrm{PGE}_{2}\right)$ concentrations were measured using Correlate-EIA assay (A competitive immunoassay kit, Assay Designs Inc., USA). The values of $\mathrm{PGF}_{2}$ and $\mathrm{PGE}_{2}$ standard curves ranged from 3.0 $\mathrm{pg} / \mathrm{ml}$ to $50 \mathrm{pg} / \mathrm{ml}$. Sensitivity value of the assay was reported to be $6.8 \mathrm{pg} / \mathrm{ml}$. Cross reaction was 3.6 and $0.8 \%$ against $\mathrm{PGF}_{2 \mathrm{\alpha}}$ and $\mathrm{PGE}_{2}$, respectively and $<0.1 \%$ for the other metabolites of prostaglandin. The intra- and inter- assay variation coefficients were 8.2 and 6.1 , respectively.

\section{Statistical Analysis}

Data were analyzed using the General Linear Models (GLM) procedure of SAS linear program (1996). Differences between two between means of the experimental groups were tested for significance using Duncan's New Multiple Range Test (Duncan, 1955). The area under $\mathrm{PGF}_{2 \leftleftarrows}$ and $\mathrm{PGE}_{2}$ curve throughout the period from 12 to 20 days post-insemination was calculated by Autocad program (2000). These data were analyzed according to the following model :

Where:

$$
\begin{aligned}
Y_{i j} & =\mu+G_{i}+e_{i j} \\
Y_{i j} & =\text { any } j^{\text {th }} \text { observation in } i^{\text {th }} \text { group, } \\
\mu & =\text { overall mean, } \\
G_{i} & =\text { effect of } i^{\text {th }} \text { group } i=1-2, \\
e_{i j} & =\text { random error. }
\end{aligned}
$$

\section{RESULTS}

\section{1-Progesterone Concentration}

Within the 21 days post- insemination, progesterone $\left(\mathrm{P}_{4}\right)$ increased to reach the level of $\geq 1.0 \mathrm{ng} / \mathrm{ml}$ between days 4 and 6 before increasing exponentially to reach its maximum concentration at day 11 in non-pregnant cows $\left(\mathrm{G}_{2}\right) . \mathrm{P}_{4}$ continued to increase up to the end of the experimental period $(>6.0 \mathrm{ng} / \mathrm{ml}$ around day 21) in pregnant ones $\left(\mathrm{G}_{1}\right)$ (Figure 1).

According to the trend of increase of $\mathrm{P}_{4}$ in $\mathrm{G} 2$, the pattern could be divided into three phases; ascending (day 0- day 10); plateau (day 10 - day 17) and descending (day 17 - day 21). These phases were not corresponded in G1, where only two phases were detected; the ascending one (day 0 - day 14) and plateau (day 14 - day 21).

$\mathrm{P}_{4}$ concentration in $\mathrm{G} 1$ at day five was about three times higher than in $\mathrm{G}_{2}(2.8$ $\mathrm{ng} / \mathrm{ml}$ vs. $0.8 \mathrm{ng} / \mathrm{ml})$. Area under $\mathrm{P}_{4}$ curve in $\mathrm{G}_{1}$ was higher $(\mathrm{P}<0.05)$ than in $\mathrm{G} 2$ during the period from day 3 to day 8 and from day 11 to day 21 , while it was insignificant during rest days.

\section{2- Prostaglandins Concentration}

Prostaglandin $F_{2}\left(P_{2}\right)$ concentrations were lower in $G_{1}$ than in $G_{2}$ during the period from day 12 to day 20 post-insemination. The maximum variation in concentration $\mathrm{PGF}_{2}$ in the two studied groups was observed at day 17 (Figure 2 and Table 1) post-insemination (time of starting descending phase of $\mathrm{P}_{4}$ in non-pregnant cows).

In contrast, prostaglandin $E_{2}\left(P E_{2}\right)$ concentration was higher in $G_{1}$ than in $G_{2}$ between day 12 and day 20 post-insemination. The maximum difference of $\mathrm{PGE}_{2}$ concentration between $\mathrm{G}_{1}$ and $\mathrm{G}_{2}$ was observed at day 16 post-insemination (Figure 3 and Table 1). 


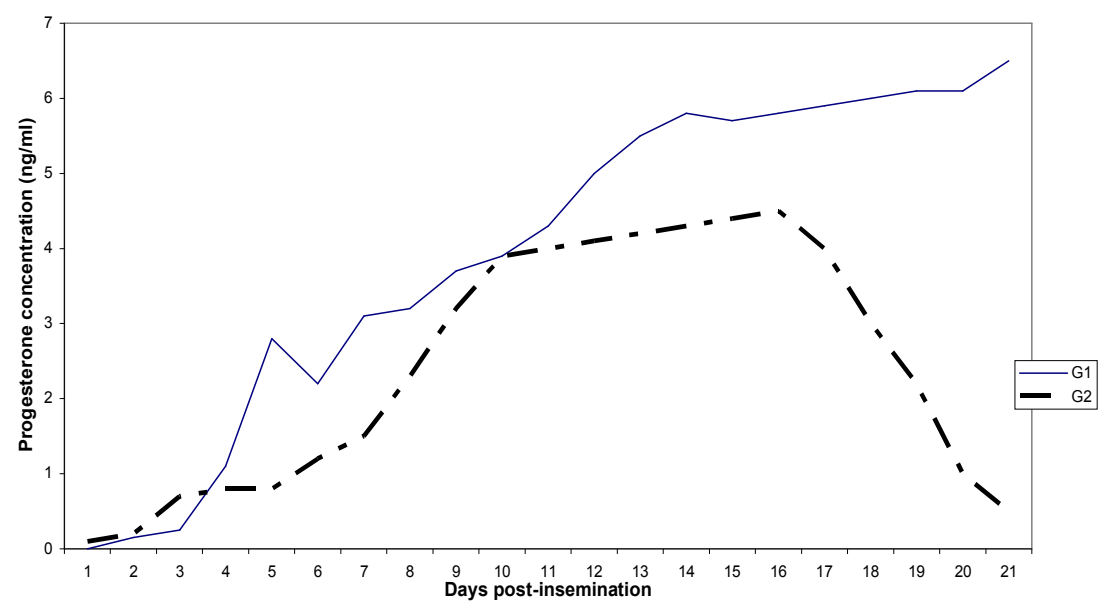

Figure 1: Progesterone concentration (ng/ml) in pregnant (G1) and non-pregnant (G2) cows during the first 21 days post-insemination

$\mathrm{PGE}_{2} / \mathrm{PGF}_{2}$ ratio during the period from day 12 to day 20 post-insemination was higher in $G_{1}$ than in $G_{2}$ (Figure 4). The interesting point to be noted is that $\mathrm{PGE}_{2} / \mathrm{PGF}_{2}$ ratio at day 17 post-insemination was $2.8 \pm 0.1$ in $\mathrm{G}_{1}$ vs. $0.4 \pm 0.1$ in $\mathrm{G}_{2}$. In $\mathrm{G}_{1} \mathrm{PGE}_{2} / \mathrm{PGF}_{2 \boldsymbol{\alpha}}$ ratio at day 16 and 17 post-insemination was 4.2 and 7 folds, respectively, in comparison with cows of $\mathrm{G}_{2}$. Another interesting finding is that the area under $\mathrm{PGE}_{2}$ curve throughout the period from 12 to 20 days post-insemination was insignificantly larger in $\mathrm{G}_{1}$ than in $\mathrm{G}_{2}$, (7.89 vs. 5.87 arbitrary units of $\mathrm{cm}^{2}$, respectively), while the area under $\mathrm{PGF}_{2 \alpha}$ curve had a contrasting trend (5.06 vs. 8.07 arbitrary units of $\mathrm{cm}^{2}$ in $\mathrm{G}_{1}$ and $\mathrm{G}_{2}$, respectively). This may indicate the luteolytic activity in $\mathrm{G}_{2}$ than $\mathrm{G}_{1}$.

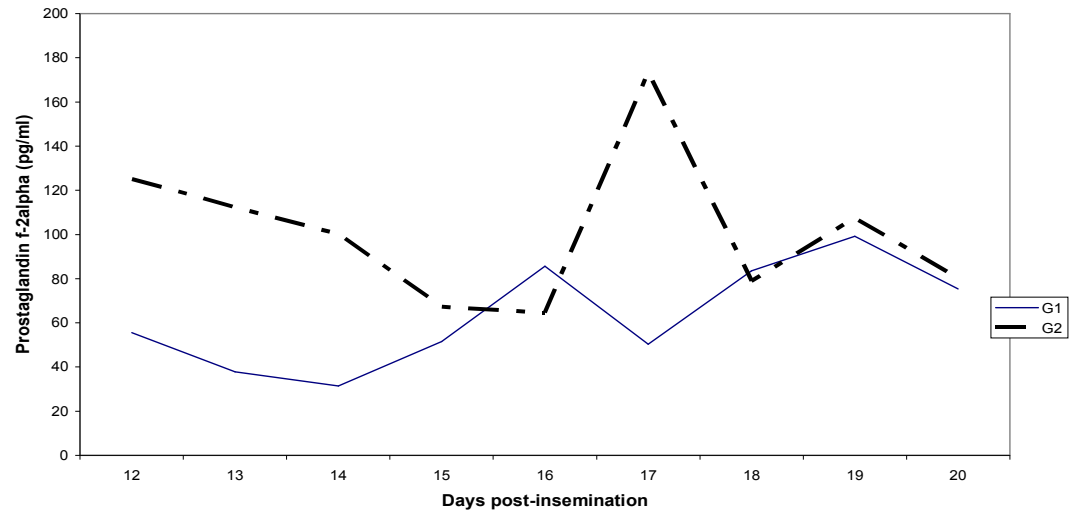

Figure 2: Prostaglandin F-2 alpha concentration (pg/ml) in pregnant (G1) and nonpregnant (G2) cows during the period from day 12 to day 20 post-insemination 
Table 1. Means ( $\pm \mathrm{SE}$ ) of $\mathrm{PGF}_{2 \mathrm{r}}$ and $\mathrm{PGE}_{2}$ concentrations $(\mathrm{pg} / \mathrm{ml})$ in pregnant (G1) and non-pregnant (G2) Friesian cows from day 12 to day17 postinsemination

\begin{tabular}{ccccc}
\hline Days & \multicolumn{2}{c}{ PGF $_{2 \mathrm{a}}$} & \multicolumn{2}{c}{ PGE $_{2}$} \\
\cline { 2 - 5 } & $\mathrm{G}_{1}$ & $\mathrm{G}_{2}$ & $\mathrm{G}_{1}$ & $\mathrm{G}_{2}$ \\
\hline 12 & $55.6 \pm 26.1^{\mathrm{a}}$ & $125.1 \pm 16.3^{\mathrm{ab}}$ & $85.1 \pm 22.4^{\mathrm{a}}$ & $136.1 \pm 43.5^{\mathrm{ab}}$ \\
13 & $37.8 \pm 12.0^{\mathrm{a}}$ & $112.3 \pm 48.3^{\mathrm{ab}}$ & $123.4 \pm 43.4^{\mathrm{a}}$ & $94.0 \pm 41.4^{\mathrm{ab}}$ \\
14 & $31.4 \pm 10.4^{\mathrm{a}}$ & $100.2 \pm 45.3^{\mathrm{ab}}$ & $105.3 \pm 41.9^{\mathrm{a}}$ & $108.4 \pm 40.7^{\mathrm{ab}}$ \\
15 & $51.5 \pm 19.9^{\mathrm{a}}$ & $67.3 \pm 24.2^{\mathrm{ab}}$ & $82.8 \pm 24.8^{\mathrm{a}}$ & $69.1 \pm 33.1^{\mathrm{ab}}$ \\
16 & $85.6 \pm 35.2^{\mathrm{ab}}$ & $64.6 \pm 16.3^{\mathrm{ab}}$ & $156 . \pm 26.0^{\mathrm{a}}$ & $40.4 \pm 15.3^{\mathrm{b}}$ \\
17 & $50.3 \pm 28.4^{\mathrm{a}}$ & $173.3 \pm 36.3^{\mathrm{b}}$ & $123.3 \pm 13.6^{\mathrm{a}}$ & $70.2 \pm 40.2^{\mathrm{ab}}$ \\
\hline
\end{tabular}

$\mathrm{a}, \mathrm{b}$ in the same row means with different superscripts are significantly different $(\mathrm{P}<0.05)$

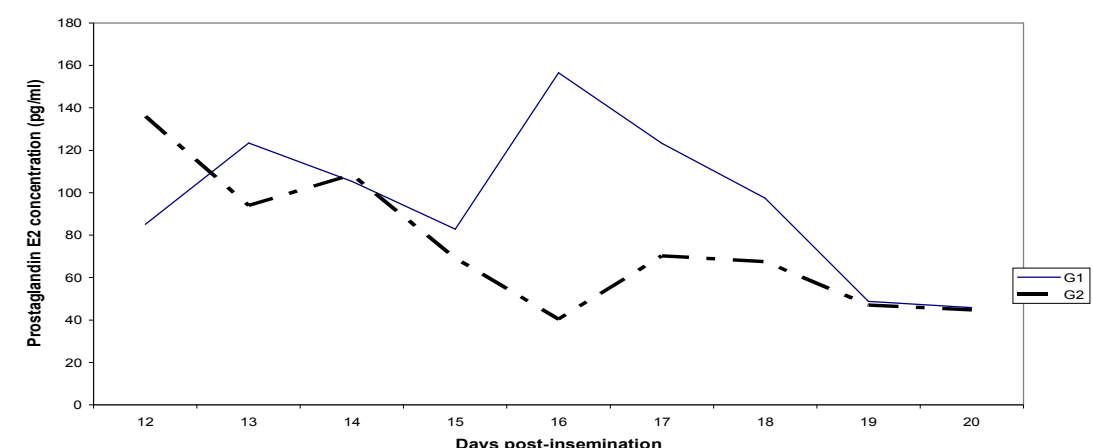

Figure 3: Prostaglandin E2 concentration (pg/ml) in pregnant (G1) and non-pregnant (G2) cows during the period from day 12 to day 20 post-insemination

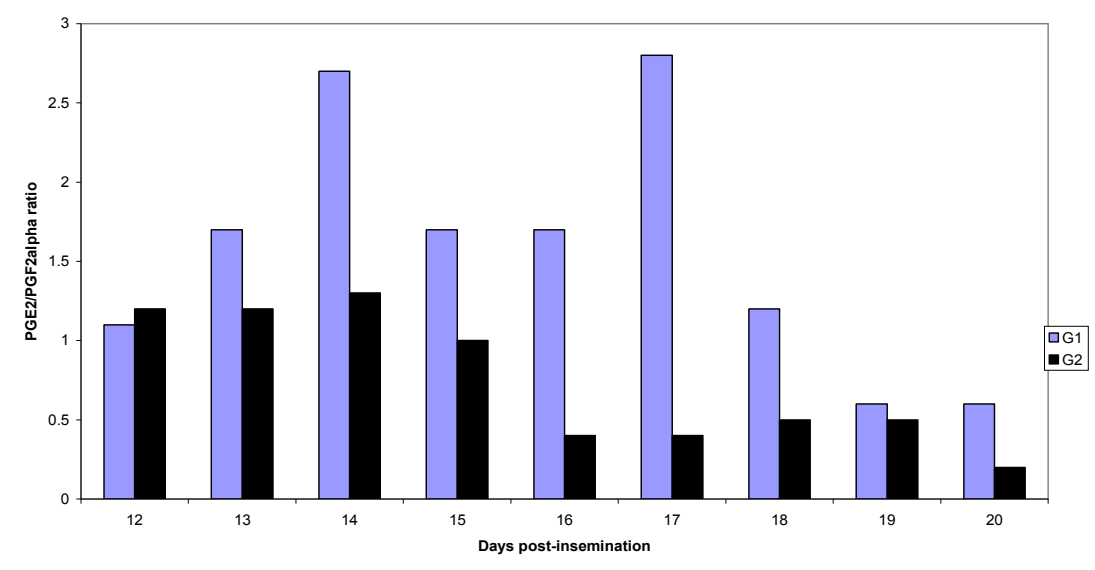

Figure 4: PGE2/PGF2alpha ratio in pregnant (G1) and non-pregnant (G2) cows during the period from day 12 to day 20 post-insemination 


\section{DISCUSSION}

The present findings of $\mathrm{P}_{4}$ concentration in pregnant and non-pregnant Friesian cows (Figure 1) agree with the findings of Oyedipe et al. (1986), Peters (1996) and Royal et al. (2000). The high level of progesterone in pregnant cows is due to the maintenance of corpus luteum (CL) (Peters, 1996; Mann et al., 1999 and Niswender et al., 2000) to support pregnancy (Spencer and Bazer, 2002 and Inskeep, 2004). Maintaining CL is mainly due to the secretion of interferon-tau (IFN- -5 ) by the embryos which inhibits the mechanism of luteolysis of CL (Peters,1996).

Increasing $\mathrm{PGF}_{2 \mathrm{~d}}$ concentration in non-pregnant $v s$. its decrease in pregnant around days 16-17 (maternal recognition period) (Figure 2) is in accordance with the findings of Bazer et al.(1991) and Okuda et al.(2002). Secretion of IFN-r, inhibits enzyme(s) necessary for $\mathrm{PGF}_{2 \mathbb{\alpha}}$ synthesis (Bazer et al., 1991).

High concentration of $\mathrm{PGF}_{2 \boldsymbol{a}}$ in non-pregnant cows is most probably attributed to the direct effect to increase oxytocin from uterine endometrium (Peters and Ball, 1995 and Peters, 1996). Increase of Oxytocin in non-pregnant cows is due to the increase of estradiol-17 concentration (Inskeep,2004) accompanying the growth of new follicles.

Pattern of $\mathrm{PGE}_{2}$ secretion agrees with that of Asselin et al. (1997); Parent et al. (2002) and Inskeep (2004) who reported that $\mathrm{PGE}_{2}$ concentration is higher in pregnant than in non-pregnant animals. Stimulation of $\mathrm{PGE}_{2}$ secretion may be a response to the secretion of IFN- $\tau$ which acts as the mechanism of maternal recognition in bovine. The obtained ratio $\mathrm{PGE}_{2} / \mathrm{PGF}_{2 \alpha}$ (Figure 4) is in agreement with the studies of Parent et al. (2002) and Inskeep (2004).

The increase in $\mathrm{PGE}_{2}$ in $\mathrm{G}_{1}$ is due to the rapid increase of of cyclooxygenase (COX-2) enzyme (Parent et al., 2002) as a result of IFN- $\tau$ increase. The enzyme inhibits the conversion of $\mathrm{PGE}_{2}$ to $\mathrm{PGF}_{2 \mathrm{a}}$ by a putative 9-Keto-prostaglandin $\mathrm{E}_{2}$ (Asselin and Fortier, 2000) and may transform the response of endometrium to oxytocin from the stimulation of $\mathrm{PGF}_{2}$ to the stimulation of $\mathrm{PGE}_{2}$ (Asselin et al.,1997).

However, while this study arrived at a description of hormonal balance during summer season, another study is needed to compare between the levels of hormone during winter and summer seasons.

\section{REFERENCES}

Al-Katanani, Y. M, F. F. Paula-Lopes and P. J. Hansen, 2002. Effect of season and exposure to heat stress on oocyte competence in Holstein cows. J. Dairy Sci. 85:390-396

Asselin, E. and M. A. Fortier, 2000. Detection and regulation of the messenger for a putative bovine endometrial 9-keto-prostaglandin $E_{2}$ reductase: effect of oxytocin and interferon-tau. Biology Reproduction 62:125-131.

Asselin, E., D. Lacroix and M.A. Fortier, 1997. IFN- $\tau$ increases $\mathrm{PGE}_{2}$ production and COX-2 gene expression in the bovine endometrium in vitro. Mol Cell Endocrinol:132:117-126.

Autocad Procedure Guide:Drawing, Version (2000) Edition, 2004. Autocad by Sybex. 
Bazer, F.W., W.W. Thatcher, P.J. Hansen, M.A. Mirando, F.L. Ott, and C. Plante, 1991. Physiological mechanisms of pregnancy recognition in ruminants. J. Reprod Fertil Suppl. ; 43:39-47.

Duncan, D.B., 1955 Multiple range and multiple F test. Biometrics, 11:1 -42.

Dunne, L.D., M.G Diskin and J.M. Sreenan, 2000. Embryo and fetal loss in beef heifers between day 14 of gestation and full term. Animal Reproduction Science, 58:39-44

El-Keraby, F.E. and M.B. Aboul-Ela, 1982. A study of some non genetic factors affecting post-partum reproductive performance in Friesian cows. Tropical Anim., 7:307.

Hansen, P.J. and C.F. Arechiga, 1999. Strategies for managing reproduction in the heat-stressed dairy cow. Journal of Animal Science 77(Suppl. 2): 36-50.

Hansen, P.J., M. Drost, R.M. Rivera, F.F. Paula-Lopes, Y.M. Al-Katanani, C.E. Krininger and C.C. Chase, 2001. Adverse impact of heat stress on embryo production: causes and strategies for mitigation. Theriogenology 55 (1): 91-103.

.Inskeep, E.K., 2004. Preovulatory, postovulatory and postmaternal recognition effects of progesterone concentrations on embryonic survival in the cow. .J.Animal Science, 82:E24-E39.

Mann,G.E. and G.E. Lamming, 2001. Relationship between maternal endocrine environment, early embryo development and inhibition of the luteolytic mechanism in cows. Reproduction,121:175-180.

Mann, G.E., G.E. Lamming, R.S. Robinson and D.C. Wathes, 1999. The regulation of interferon-tau production and uterine hormone receptors during early pregnancy. J. Reproduction and Fertility Suppl,54:317-328.

Niswender, G. D., J.L. Juengel, P.J. Silva, M.K. Rollyson and E.W. McIntush, 2000. Mechanisms controlling the function and life span of corpus luteum. .Physiology Review, 80(1):1-29.

NRC, 1988. Nutrient Requirements of Dairy Cattle. National Academy of Science, Washington, D. C. USA.

Oyedipe, E.O., A.A. Voh, B.N. Marire and N. Pathiraja, 1986. Plasma progesterone concentrations during the oestrous cycle and following fertile and non-fertile inseminations of Zebu heifers. British Vetrenary, 142: 41-46.

Okuda, K., Y. Miyamoto, D.J. Skarznski, 2002. Regulation of endometrial prostaglandin F (2alpha) synthesis during luteolysis and early pregnancy in cattle. Domestic Animal Endocrinology. Jul, 23 (1-2): 255-264.

Parent, J., P. Chapdelaine, J. Sirois, M.A. Fortier, 2002 Expression of microsomal prostaglandin $\mathrm{E}$ syntheses in bovine endometrium: coexpression with cyclooxygenase type 2 and regulation by interferon-tau. Endocrinology, Vol.143, No.8: 2936-2943.

Peters, A.R., 1996. Embryo mortality in the cow. Animal Breeding Abstracts Vol.64,No.8: 587-598.

Peters, A.R. and P.J.H. Ball, 1995. Reproduction in cattle, $2^{\text {nd }}$ edition, Blackwell Science, Oxford.

Royal, M., G.E. Mann and A.P.F. Flint, 2000. Strategies for reversing the trend towards subfertility in dairy cattle. The veterinary Journal, 160,53-60.

SAS Procedure Guide: Statistics, Version 6.12 Edition, 1996. SAS Institute Inc., Cary, NC. USA. 
Schams, D. and B. Berisha, 2004. Regulation of corpus luteum function in cattle-an overview. Reprod Domest Anim. 39 (4) :241-51.

Spencer, T.E. and F.W. Bazer, 2002. Biology of progesterone action during pregnancy recognition and maintenance of pregnancy. Front Bioscience, 1 (7):1879-1898 
النموذج الهرموني المصاحب لثبوت الحمل فى أبقار الفريزيان وعلاقته بظروف موسم الصيف في مصر

سويفى عبد الرحيم سويفى'، فكرى السيد القربى'، سيد على احمد عيسوى' ، اثرف هثام برقاوى"

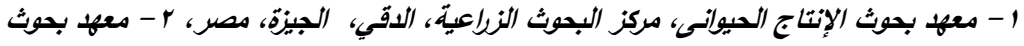

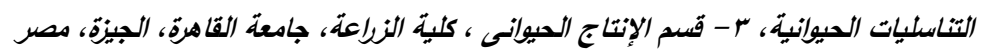

أجريت هذه الدراسة على 17 بقرة فريزيان متعددة الولادات تم تلقيحها خلال موسم الصيف (يونيه -

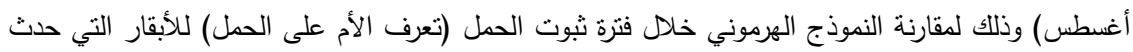

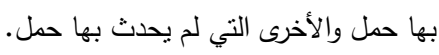
تم ملاحظة الثياع ثلاث مرات يوميا وتم تلقيح مجموعة من الأبقار التي ثبت شيا عها بالسائل المنوي المجدد

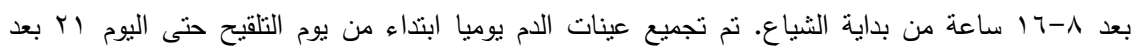
PGF

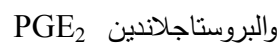

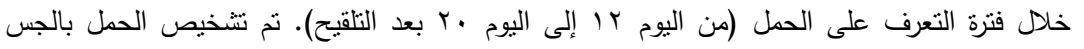

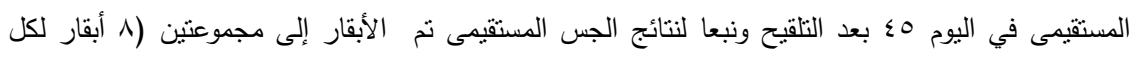

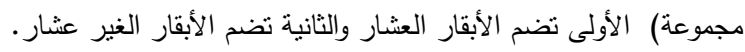

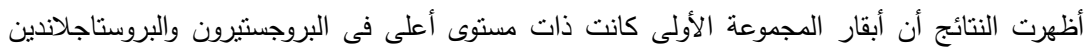
من أبقار المجموعة الثانية بينما كان مستوى البروستاجلاندين PGE

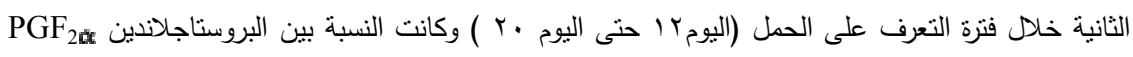

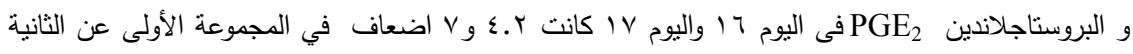

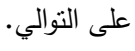

